\title{
Properties of Calcium Acetate Manufactured with Etching Waste Solution and Limestone Sludge as a Cementitious High-Early-Strength Admixture
}

\author{
Deuck-Mo Kim, ${ }^{1}$ Hwa-Sung Ryu, ${ }^{1}$ Sang-Heon Shin, ${ }^{1}$ and Won-Jun Park ${ }^{2}$ \\ ${ }^{1}$ Hanyang Experiment and Consulting, Hanyang University, ERICA Campus, Ansan 15588, Republic of Korea \\ ${ }^{2}$ Department of Building System Engineering, Kangwon National University, Samcheok 25913, Republic of Korea \\ Correspondence should be addressed to Hwa-Sung Ryu; rhsung73@hanyang.ac.kr
}

Received 1 February 2016; Revised 12 May 2016; Accepted 17 May 2016

Academic Editor: Kaveh Edalati

Copyright ( $\odot 2016$ Deuck-Mo Kim et al. This is an open access article distributed under the Creative Commons Attribution License, which permits unrestricted use, distribution, and reproduction in any medium, provided the original work is properly cited.

Concrete is one of the most widely used construction materials. There are several methods available to improve its performance, with one of them being the use of high-early-strength admixtures (HESAs). Typical HESAs include calcium nitrate, calcium chloride, and calcium formate (CF). Industrial by-products, such as acetic acid and lime stone sludge (LSS), can be used together to produce calcium acetate (CA), which can subsequently be used as a cementitious HESA. In this study, calcium carbonate and LSS were mixed with cement in weight ratios of $1: 1,1: 1.5$, and $1: 2$, and the properties of the as-produced CA were evaluated. CA and CF were mixed with cement in different weight ratios $(0,1,2$, and $3 \mathrm{wt} \%)$ to obtain CA- and CF-mortars, respectively. The flow behavior, setting time, $\mathrm{pH}$, and compressive strength of these mortars were evaluated, and their X-ray diffraction patterns were also analyzed. It was found that as the CF content in the CF-mortar increased, the initial strength of the mortar also increased. However, it impaired its long-term strength. On the other hand, when $1 \%$ CA was mixed with cement, satisfactory early and long-term strengths were achieved. Thus, CA, which is obtained from industrial by-products, can be an effective HESA.

\section{Introduction}

Several methods such as accelerated curing and the use of precast concrete and construction robots are used for increasing the production rate in ferroconcrete construction [1-7]. In particular, it is important to reduce the concrete curing time to reduce the overall concrete construction period. The overall performance and development of concrete are significantly influenced by both the curing process and the subsequent cast removal. Some of the methods currently used to improve these characteristics include steam curing and the use of high-early-strength admixtures (HESAs) [813]. Accelerated curing however requires the use of costly equipment. On the other hand, in the case of HESAs, an admixture addition of just $1-3 \mathrm{wt} \%$ is required to enhance the concrete performance, rendering this method more costeffective. In addition, with an increase in the use of blended cements and cementitious composites, the use of various HESAs as a supplement to low-early-strength cements such as the ground-granulated blast-furnace slag has increased to improve their performance [14-17]. The primary mechanisms for such HESAs include the enhancement of the production of calcium silicate hydrate (C-S-H) using highly soluble calcium ions or increasing the hydration of amphoteric aluminum ions [18-21]. Generally, calcium nitrate, calcium chloride, and highly soluble calcium formate (CF) are used as HESAs to produce calcium salts, and amine mixtures are used to enhance the hydration of aluminum ions $[9,22,23]$.

The semiconductor and steel industries produce a wide array of by-products including acetic acid and calcium salts. The amount of chemical substances used for etching thin film transistor-liquid crystal display boards in the semiconductor industry continues to increase. Etching is used to corrode a material with chemicals such as nitric acid and acetic acid to polish its surface and create a product with desired properties. The chemicals used for etching can be recycled by distillation [24]. Such substances have a lower solid content than the pure substances and use water as a solvent. According to the World 
TABLE 1: Chemical composition of $\mathrm{CaCO}_{3}$ and LSS (\%).

\begin{tabular}{lccccccccc}
\hline & $\mathrm{CaO}$ & $\mathrm{SiO}_{2}$ & $\mathrm{MgO}$ & $\mathrm{Al}_{2} \mathrm{O}_{3}$ & $\mathrm{SO}_{3}$ & $\mathrm{Fe}_{2} \mathrm{O}_{3}$ & $\mathrm{P}_{2} \mathrm{O}_{5}$ & $\mathrm{~K}_{2} \mathrm{O}$ & $\mathrm{Na}_{2} \mathrm{O}$ \\
\hline $\mathrm{CaCO}_{3}$ & 96.08 & 0.98 & 2.06 & 0.39 & 0.02 & 0.36 & 0.00 & 0.11 & 0.00 \\
\hline Limestone sludge & 90.46 & 3.81 & 1.06 & 2.06 & 0.08 & 1.35 & 0.70 & 0.45 & 0.04 \\
\hline
\end{tabular}

Steel Association, the total global steel production in 2014 was over 12,700,000,000 tons [25]. The process of steelmaking commences by cleansing limestone, which is obtained by dehydration of the by-products produced during desulfurization, with water to produce quicklime. The quicklime so obtained is used as a raw material to produce steel. During this process, small limestone particles $(<1 \mathrm{~mm})$ are separated by precipitation and thus lime stone sludge (LSS) can be manufactured through a filter press process. LSS contains large quantities of water, which renders it uneconomical for recycling [26].

In this study, we manufactured a calcium-containing HESA (calcium acetate, CA), which is a source of calcium ions, by reacting acetic acid with LSS, which is a by-product of various industrial processes and evaluated the performance of the admixture so obtained. For a thorough evaluation, we examined the viscosity, density, $\mathrm{pH}$, calcium content, heavy metal content, and solid content of the resultant admixture. We also added this admixture in different weight ratios to cementitious composites or mortars and examined their fluidity, setting time, $\mathrm{pH}$, and compressive strength. We also carried out an X-ray diffraction (XRD) analysis of the cementitious composites or mortars containing this admixture.

\section{Materials and Methods}

\subsection{Materials}

2.1.1. Limestone Sludge. In this study, LSS, which is obtained from industrial by-products, was used to manufacture the calcium-containing HESAs. The XRD pattern and chemical composition analyses of LSS are shown in Figure 1 and Table 1 , respectively. The XRD patterns of both $\mathrm{CaCO}_{3}$ and LSS showed the presence of a $\mathrm{CaCO}_{3}$ peak at approximately $29^{\circ}$. The structure of LSS appears to be identical to that of $\mathrm{CaCO}_{3}$. However, considering the chemical composition, the $\mathrm{CaO}$ content in LSS was approximately $5.84 \%$ lesser than that in $\mathrm{CaCO}_{3}$. In addition, LSS also contained $\mathrm{SiO}_{2}$ and metallic salts such as $\mathrm{Al}_{2} \mathrm{O}_{3}$ and $\mathrm{Fe}_{2} \mathrm{O}_{3}$.

2.1.2. Recycled Acetic Acid. Recycled acetic acid (RAA) was obtained from the previous etching processes by extraction via an acid separation process. In this study, approximately $60 \%$ RAA was used. Figure 2 shows the Fourier transform infrared (FT-IR) spectrum of RAA. In the FT-IR spectrum of RAA, the peaks in the range of $3300-2500 \mathrm{~cm}^{-1}$ correspond to organic acids containing carboxylic groups. The peaks associated with $\mathrm{C}=\mathrm{O}$ groups $\left(1760-1690 \mathrm{~cm}^{-1}\right)$ and $\mathrm{C}-\mathrm{O}$ groups $\left(1320-1210 \mathrm{~cm}^{-1}\right)$ can also be observed in this spectrum. Some examples of carboxylic acids include acetic acid,

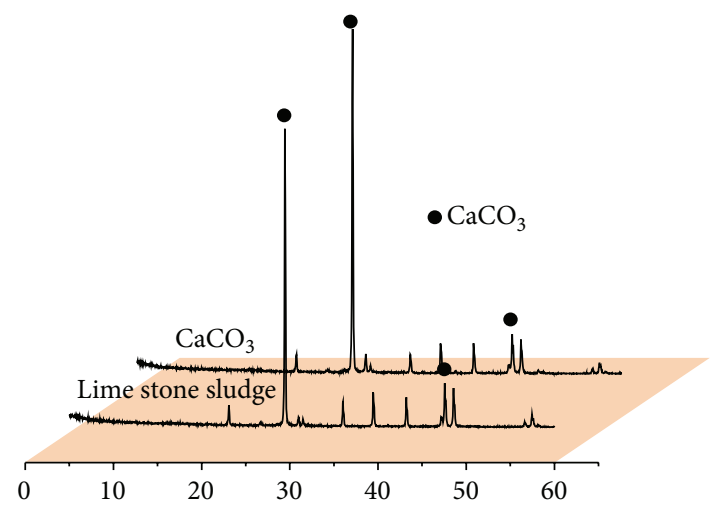

FIgURE 1: XRD patterns of $\mathrm{CaCO}_{3}$ and LSS.

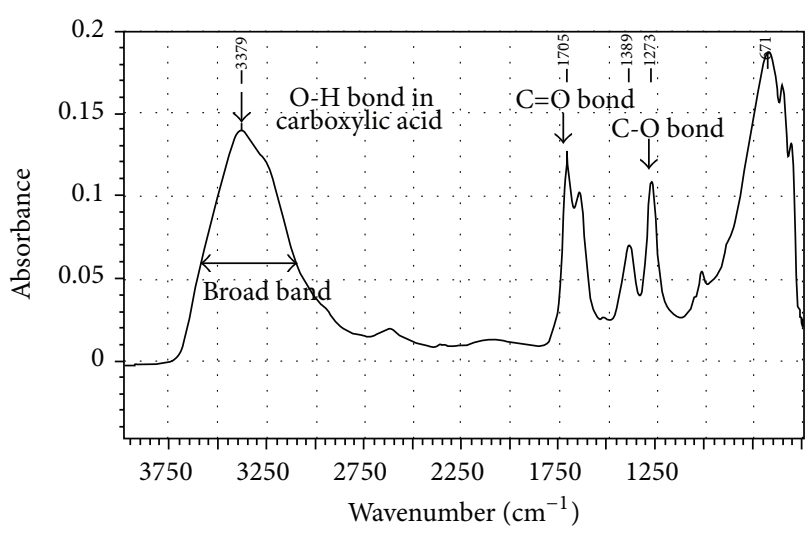

FIGURE 2: FT-IR spectrum of RAA.

formic acid, gluconic acid, and propionic acid. Hence, it was confirmed that RAA contained carboxylic acid groups [27].

2.1.3. Binder and Sand. A comparison between the properties of the conventional HESAs and the admixture produced in this study was performed by using mortar specimens. The mortar specimens consisted of class I ordinary Portland (OPC). The chemical compositions and physical properties of these materials are given in Tables 2 and 3, respectively. A description of the sand used in this study is given in Table 4.

\subsection{Methods}

2.2.1. Overview. In this study, we manufactured both the CA and the mortars containing CA in different weight ratios $(0$, 1,2 , and $3 \mathrm{wt} \%$ ) and evaluated the performance of these mortars. The viscosity, density, and $\mathrm{pH}$ of these mortars were evaluated. Their inductively coupled plasma mass spectroscopy 
TABLE 2: Chemical composition of binder (\%).

\begin{tabular}{lcccccccc}
\hline $\mathrm{CaO}$ & $\mathrm{SiO}_{2}$ & $\mathrm{MgO}$ & $\mathrm{Al}_{2} \mathrm{O}_{3}$ & $\mathrm{SO}_{3}$ & $\mathrm{Fe}_{2} \mathrm{O}_{3}$ & $\mathrm{P}_{2} \mathrm{O}_{5}$ & $\mathrm{~K}_{2} \mathrm{O}$ & $\mathrm{Na}_{2} \mathrm{O}$ \\
\hline 63.85 & 21.09 & 3.32 & 4.84 & 3.09 & 2.39 & 0.36 & 0.73 & 0.14 \\
\hline
\end{tabular}

TABLE 3: Physical properties of ordinary Portland cement (OPC).

\begin{tabular}{lcccccc}
\hline \multirow{2}{*}{ Specific gravity } & \multirow{2}{*}{ Blaine specific surface $\left(\mathrm{cm}^{2} / \mathrm{g}\right)$} & \multicolumn{2}{c}{ Setting time } & \multicolumn{3}{c}{ Compressive strength of mortar (MPa) } \\
& & Initial set $(\mathrm{min})$ & Final set (hour) & 3 days & 7 days & 28 days \\
\hline 3.15 & 3400 & 400 & 7 & 20 & 23 & 38 \\
\hline
\end{tabular}

TABLE 4: Properties of fine aggregate.

\begin{tabular}{lcccc}
\hline Maximum size $(\mathrm{mm})$ & Unit weight $(\mathrm{kg} / \ell)$ & Specific gravity & Water absorption $(\%)$ & Solid volume percentage $(\%)$ \\
\hline$<1.2$ & 1.5 & 2.62 & 0.40 & 58.1 \\
\hline
\end{tabular}

TABLE 5: Measurements and methods.

\begin{tabular}{lccc}
\hline Experiment & Measurement sample & Properties measured & Standards \\
\hline $\begin{array}{l}\text { Calcium acetate using limestone } \\
\text { sludge and recycled acetate }\end{array}$ & Viscosity (cps) & ASTM D 2196 [28] \\
& Calcium acetate & Density $\left(\mathrm{kg} / \mathrm{m}^{3}\right)$ & ASTM D 4052-11 [29] \\
& & $\mathrm{pH}$ & - \\
& & ICP-MS analysis & ASTM D 6800-12 [30] \\
Cement matrix using accelerator & Setting time & ASTM C 191 [31] \\
& & X. & - \\
& Cement morte & Flow & ASTM C 230/230M-14 [32] \\
& & Compressive strength & ASTM C 109 [33] \\
\hline
\end{tabular}

(ICP-MS) analyses were also performed. In addition, an existing HESA (CF) was also added to mortar in different weight ratios $(0,1,2$, and $3 \mathrm{wt} \%)$ to obtain CF-mortars and their CF content, setting time, XRD patterns, and $\mathrm{pH}$ were also investigated. The flow behavior and compressive strength of the mortars were also measured. Table 5 summarizes these experiments. The flow chart for the synthesis of CA is shown in Figure 3.

2.2.2. Manufacturing CA with LSS and RAA. Here, RAA and LSS reacted to yield CA in accordance with (1). The yield was maximum when the ratio of acetic acid to $\mathrm{CaCO}_{3}$ was $2: 1$ with $1 \mathrm{~mol}$ each of CA, water, and carbon dioxide per mol of $\mathrm{CaCO}_{3}$ :

$$
\begin{aligned}
& 2 \mathrm{CH}_{3} \mathrm{COOH}+\mathrm{CaCO}_{3} \\
& \quad=\mathrm{Ca}\left(\mathrm{CH}_{3} \mathrm{COO}\right)_{2}+\mathrm{H}_{2} \mathrm{O}+\mathrm{CO}_{2}
\end{aligned}
$$

Calcium carbonate and RAA were used to compare the solubility of the LSS and acetic acid together. To $60 \%$ solid acetic acid, LSS was added in different weight ratios $(1,1.5$, or 2 ) as shown in Table 6 . This mix was reacted for $12 \mathrm{~h}$. Upon

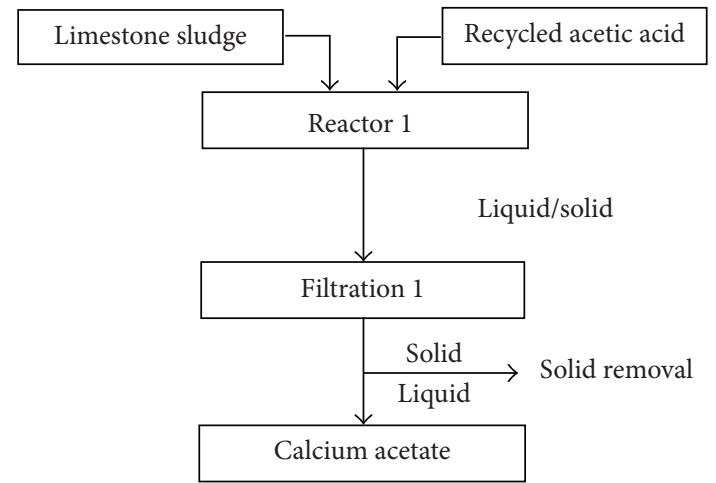

FIgURE 3: Flow diagram for CA synthesis.

mixing, the unreacted particles were removed via filtering and acetic acid was separated for future use.

2.2.3. Cementitious Composites with HESAs. The mix proportions of the cementitious composites (cement paste and mortar) that were mixed with HESAs are given in Table 7. The 


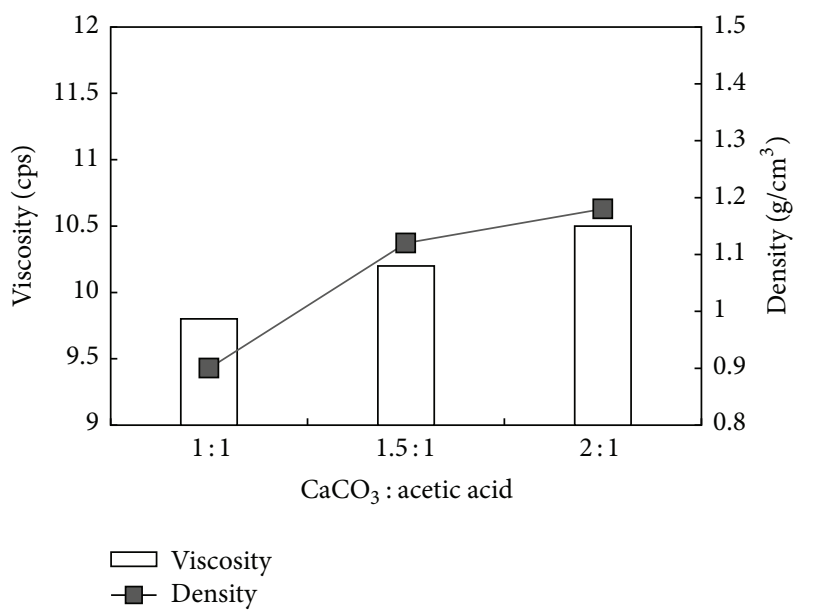

(a) $\mathrm{CA}$ made from $\mathrm{CaCO}_{3}$ and acetic acid

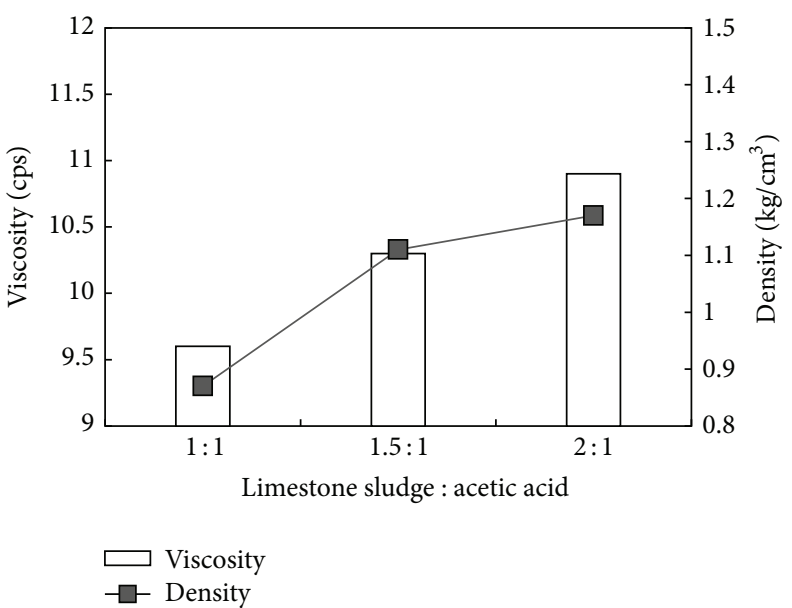

(b) CA made from sludge and acetic acid

FIGURE 4: Viscosity and density of calcium acetate.

CA (used as a HESA) was weighed such that the weight ratio of LSS to acetic acid was $2: 1$ and the $\mathrm{pH}$ of the overall mixture was 5.9. The manufactured specimen underwent steam curing at a temperature of $20^{\circ} \mathrm{C}$ and a relative humidity of $60 \%$.

The paste specimens were produced by mixing $0,1,2$, and $3 \%$ of CA and CF each with $100 \mathrm{~g}$ of OPC at a water to binder ratio of 0.32 for $3 \mathrm{~min}$. The setting time and $\mathrm{pH}$ of these specimens were evaluated. Their XRD patterns were also analyzed. The setting time was measured according to ASTM C191. The $\mathrm{pH}$ measurements were performed by collecting $10 \mathrm{~mL}$ of each material after binding and subsequently immersing them in $100 \mathrm{~g}$ of distilled water. The results were recorded at $60 \mathrm{~min}$ and $24 \mathrm{~h}$, in triplicate. For the XRD analysis, $30 \mathrm{~g}$ of the cured paste specimen was collected after 18 and $24 \mathrm{~h}$, following which it was broken down into particles of $<300 \mu \mathrm{m}$ diameter of the particles and finally immersed in acetone. The $\mathrm{X}$-ray diffractometer was operated at $45 \mathrm{KV}$ and $40 \mathrm{~mA}$ with $\mathrm{Cu}$ radiation. A scan rate of $5^{\circ} / \mathrm{min}$ was maintained over a range of $5-60^{\circ}$.

The cement mortar was manufactured by adding $135 \mathrm{~g}$ of sand to the paste composites. The sand and paste composites were mixed for $3 \mathrm{~min}$, allowed to rest for $2 \mathrm{~min}$, and finally mixed for additional $2 \mathrm{~min}$. The flow of the mixed specimen was measured according to ASTM C230. For each mixture, molds with the dimensions of $4 \mathrm{~cm} \times 4 \mathrm{~cm} \times 16 \mathrm{~cm}$ were formed, cured for $18 \mathrm{~h}$, and were immediately removed. The compressive strength was measured according to ASTM C109 at the intervals of $1,3,7$, and 28 days, in triplicate.

\section{Results and Discussion}

\section{1. $C A$}

3.1.1. $p H$ and Density of CA. The results of the viscosity and density measurements of the manufactured CA are shown in Figure 4. The viscosity and density of the CA solutions (containing $\mathrm{CaCO}_{3}$ and LSS in weight ratios) showed similar trends. The viscosity and density of the CA solutions
TABLE 6: Reaction ratio according to weight ratio of RAA : $\mathrm{CaCO}_{3}$.

\begin{tabular}{lcccc}
\hline $\mathrm{RAA}: \mathrm{CaCO}_{3}$ & $1: 0.5$ & $1: 1$ & $1: 1.5$ & $1: 2$ \\
\hline $\begin{array}{l}\text { Reaction yield (\%) } \\
\text { Reacted acetic acid }\end{array}$ & 52 & 42 & 31 & 24.97 \\
$(\%)$ & 42.4 & 80.8 & 91.6 & 99.86 \\
\hline
\end{tabular}

TABLE 7: Mixtures for paste and mortar specimens.

\begin{tabular}{lccccc}
\hline $\begin{array}{l}\text { Mixture } \\
\text { number }\end{array}$ & OPC & Water & $\begin{array}{c}\text { Calcium } \\
\text { acetate }\end{array}$ & $\begin{array}{c}\text { Calcium } \\
\text { formate }\end{array}$ & Sand \\
\hline OPC & 100 & 32 & 0 & & 135 \\
OPC-A1 $^{(\mathrm{A})}$ & 100 & 32 & 1 & & 135 \\
OPC-A2 & 100 & 32 & 2 & & 135 \\
OPC-A3 $^{2}$ & 100 & 32 & 3 & & 135 \\
OPC-F1 $^{(B)}$ & 100 & 32 & & 1 & 135 \\
OPC-F2 & 100 & 32 & & 2 & 135 \\
OPC-F3 & 100 & 32 & & 3 & 135 \\
\hline
\end{tabular}

${ }^{(\mathrm{A})} \mathrm{A}=$ calcium acetate, $1=$ cement $\times 1 \mathrm{wt} \%$.

(B) $\mathrm{F}=$ calcium formate, $1=$ cement $\times 1 \mathrm{wt} \%$.

increased with an increase in the weight ratios of $\mathrm{CaCO}_{3}$ and LSS. The density of acetic acid is $1.049 \mathrm{~g} / \mathrm{cm}^{3}$ and that of the CA is $1.509 \mathrm{~g} / \mathrm{cm}^{3}$. Thus, as a greater quantity of acetic acid reacts with $\mathrm{CaCO}_{3}$ to produce the $\mathrm{CA}$, the density of this reactant increases.

3.1.2. $\mathrm{pH}$ and Ca Ion-ICP Analysis. Figure 5 shows the results of the $\mathrm{pH}$ measurement and Ca Ion-ICP analysis of the manufactured CA. The $\mathrm{pH}$ appeared to increase slightly when calcium carbonate was used. Conversely, the $\mathrm{pH}$ was low when LSS was used as it contains small quantities of Ca. However, when the weight ratio of LSS was greater than 2, the $\mathrm{pH}$ of the $\mathrm{CA}$ produced using $\mathrm{CaCO}_{3}$ was similar to that obtained when LSS was used for producing the CA. 


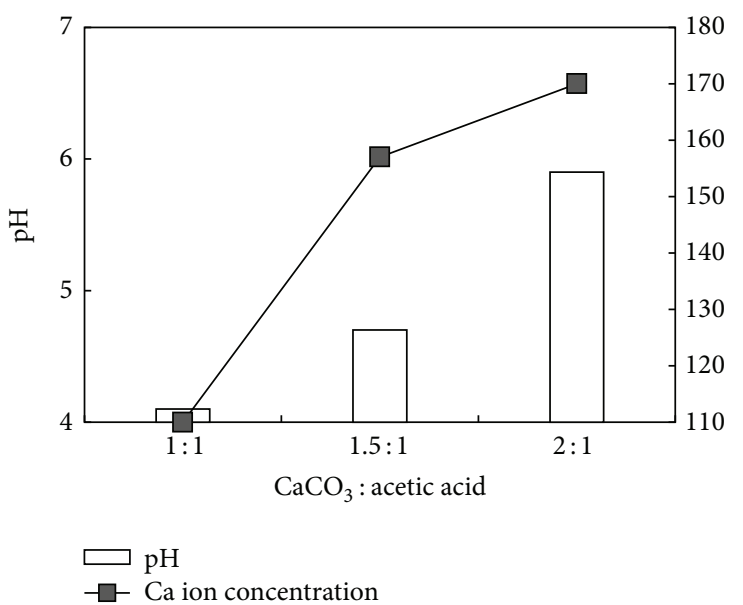

(a) $\mathrm{CA}$ made from $\mathrm{CaCO}_{3}$ and acetic acid

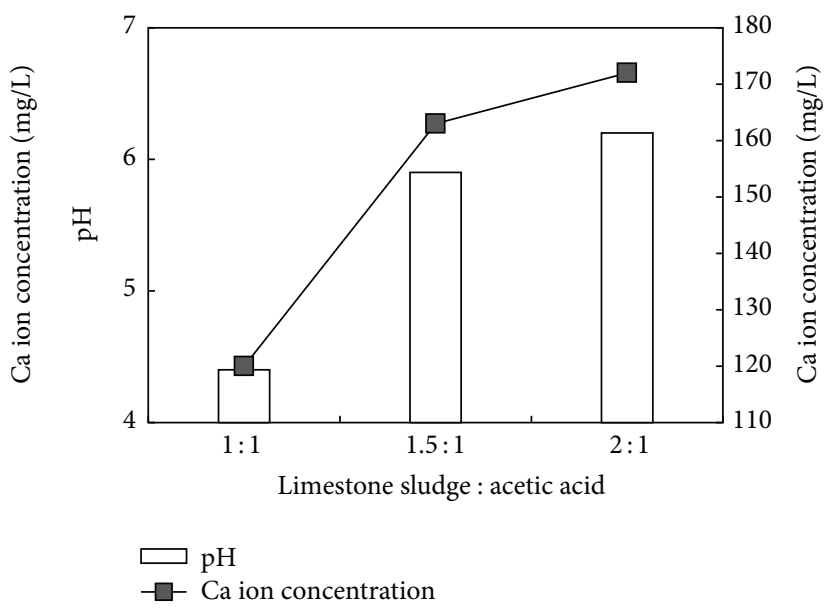

(b) CA made from limestone sludge and acetic acid

FIGURE 5: $\mathrm{pH}$ and $\mathrm{Ca}$ ion concentration of calcium acetate.

TABLE 8: ICP Analysis of heavy metals (mg/ $\ell$ ).

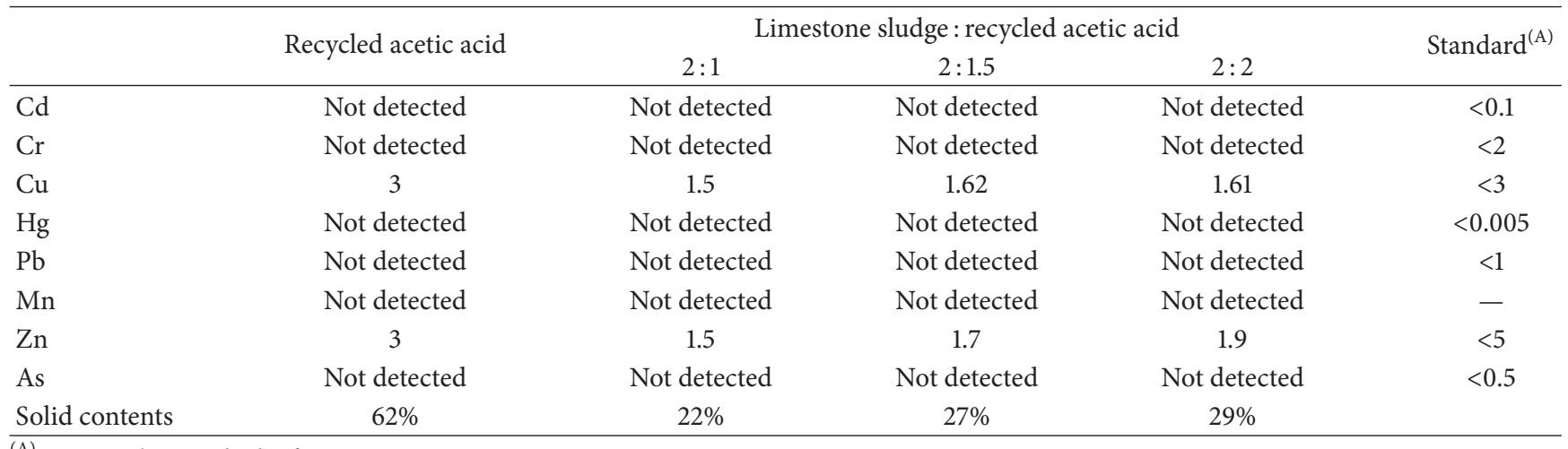

${ }^{(A)}$ Water quality standards of Japan.

3.1.3. Microelement Analysis. Table 8 shows the results of the ICP analysis of heavy metals of the manufactured CA. The microelements and solid contents of the manufactured CA are listed in Table 8. Heavy metals were not detected, indicating that the CA manufactured in this work is less hazardous to the environment than the other similar materials [34].

\subsection{Cement Composites}

3.2.1. Flow and Setting Time of Mortar. Figures 6 and 7 display the flow and setting times, respectively, of the cement mortar obtained by mixing CA with cement. It was found that, for the CA-mortar, the fluidity increased with an increase in the CA content, as shown in Figure 6. However, in the case of the CF-mortar, the fluidity decreased with an increase in the CF content.

From Figure 7, it can be observed that when CF was used and the mixing ratio was identical for the CA- and CF-mixed mortars, the initial and finish setting times were reduced. In the case of the CA-mortar, the initial setting time was reduced when the mixing ratio increased. At a CA content of $1 \%$, a minimum final setting time was obtained, which increased

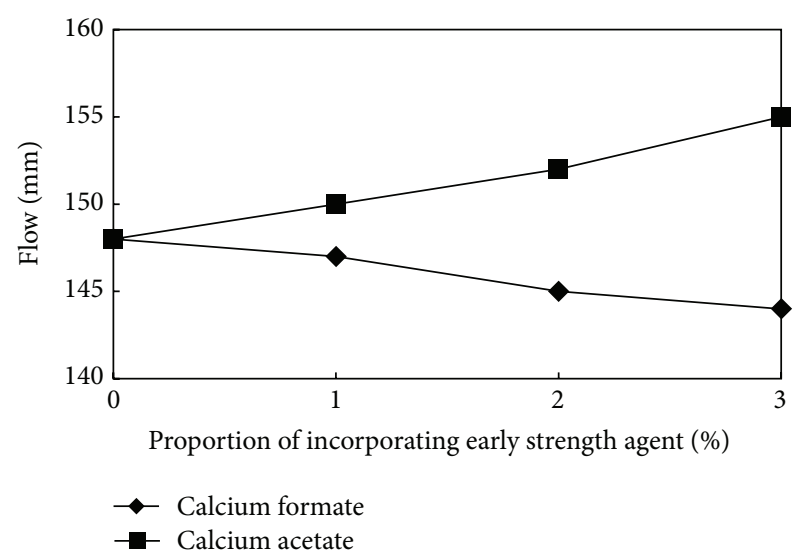

FIGURE 6: Flow test results.

as the mixing ratio increased. In case of the CF-mortar, no reversible change in the setting time was observed with a change in the mixing ratio, and the setting time decreased proportionally with a decrease in the mixture ratio. 


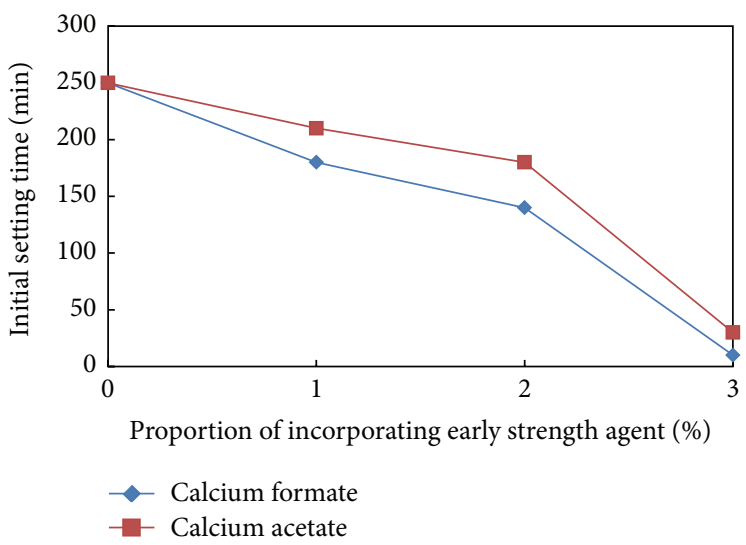

(a) Initial setting time

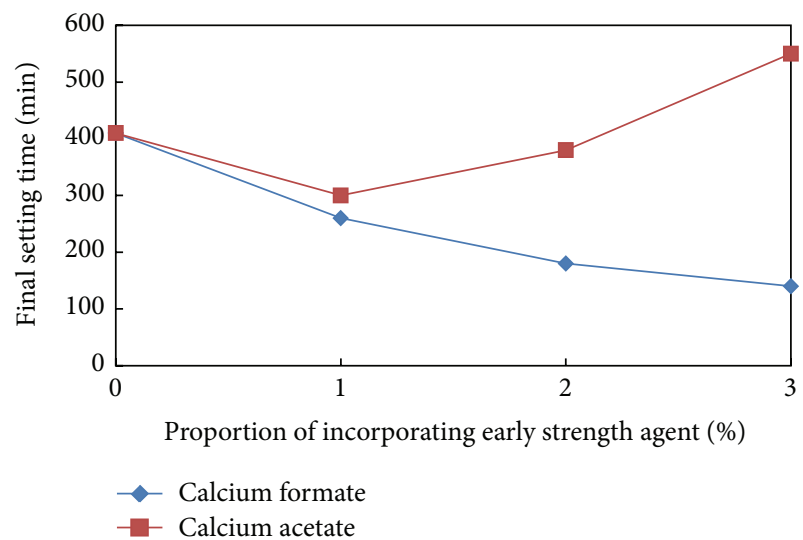

(b) Final setting time

FIGURE 7: Setting time tests results.

TABLE 9: $\mathrm{pH}$ of cement paste as a function of time.

\begin{tabular}{|c|c|c|c|c|}
\hline \multirow[t]{2}{*}{ HESA } & \multirow[t]{2}{*}{ Admixture proportion $($ cement $\times \%)$} & \multicolumn{3}{|c|}{$\begin{array}{l}\mathrm{pH} \text { of cement paste as a function of } \\
\text { time }\end{array}$} \\
\hline & & Immediate & 60 minutes & $\begin{array}{c}24 \\
\text { hours }\end{array}$ \\
\hline & OPC & 12.2 & 12.4 & 12.4 \\
\hline \multirow{3}{*}{ Calcium acetate } & OPC-A1 & 11.8 & 12.2 & 12.3 \\
\hline & OPC-A2 & 10.2 & 11.0 & 12.1 \\
\hline & OPC-A3 & 9.0 & 10.2 & 11.9 \\
\hline \multirow{3}{*}{ Calcium formate } & OPC-F1 & 12.3 & 12.2 & 12.4 \\
\hline & OPC-F2 & 12.2 & 12.3 & 12.3 \\
\hline & OPC-F3 & 12.1 & 12.2 & 12.1 \\
\hline
\end{tabular}

3.2.2. Change in $\mathrm{pH}$ of Cement Paste. The $\mathrm{pH}$ values of the cement pastes, as a function of time, are given in Table 9. In the case of the paste containing the $\mathrm{CA}$, the $\mathrm{pH}$ initially decreased with an increase in the CA content. On the other hand, in the case of the paste containing $\mathrm{CF}$, the $\mathrm{pH}$ remained relatively constant regardless of the $\mathrm{CF}$ content. When the CA content exceeded $1 \%$, the setting time was reduced. Bortoluzzi et al. reported that when $\mathrm{CaCl}_{2}(\mathrm{pH}=4.4)$ is mixed with cement, the $\mathrm{pH}$ of the cement decreases. The $\mathrm{pH}$ subsequently recovers because of the production of $\mathrm{Ca}^{2+}$, which reduces the setting time [35]. When 3\% CA is mixed, the hydration time decreases to $24 \mathrm{~h}$ and a retarding phenomenon can be observed. When CA content is more than $2 \%$, both initial $\mathrm{pH}$ decrease and setting time delay were observed because of the high solubility of CA and residual acetic acid.

3.2.3. Compressive Strength of Mortar. Figure 8 shows the compressive strengths of the CA- and CF-mortar specimens at different curing times. When a CA content of $1 \%$ was used, the compressive strength of the resulting mixture was $22 \%$ greater than that obtained when no admixture was added (i.e., for a standard specimen). When the CF content in the mortar was $2 \%$, similar strengths were obtained. When $3 \%$
CF was mixed and the mix was cured for seven days, the strength of the resulting mortar was found to be greater than that of the standard material. However, the strength started decreasing after 28 days. When $1 \%$ CA was mixed and the mix was cured for three days, the strength of the resulting mortar was over $40 \%$ greater than that of the standard specimen and was still $14 \%$ greater even after 28 days. However, when the CA content exceeded $2 \%$, the compressive strength of the material diminished because of the reduction in both the $\mathrm{pH}$ of the cement paste and the hydration of acetic acid.

3.2.4. XRD. The XRD analysis was performed on the CAand CF-mortars. Figure 9 shows the XRD patterns of the CA-mortars with different CA contents after a curing period of one day. When $1 \%$ CA was mixed, the intensity of the $\mathrm{Ca}(\mathrm{OH})_{2}$ peak decreased, while that of the calcium aluminosilicate hydrate (C-A-S-H) and C-S-H peaks increased, indicating rapid hydration. The $\mathrm{CA}$-mortar having a $\mathrm{CA}$ content of $3 \%$ showed a weaker $\mathrm{Ca}(\mathrm{OH})_{2}$ peak than that of the mortar containing no admixture. However, in the case of the CA-mortar containing $1 \%$ admixture, this peak was more intense, and the intensity of the C-A-S-H and C-S-H peaks 


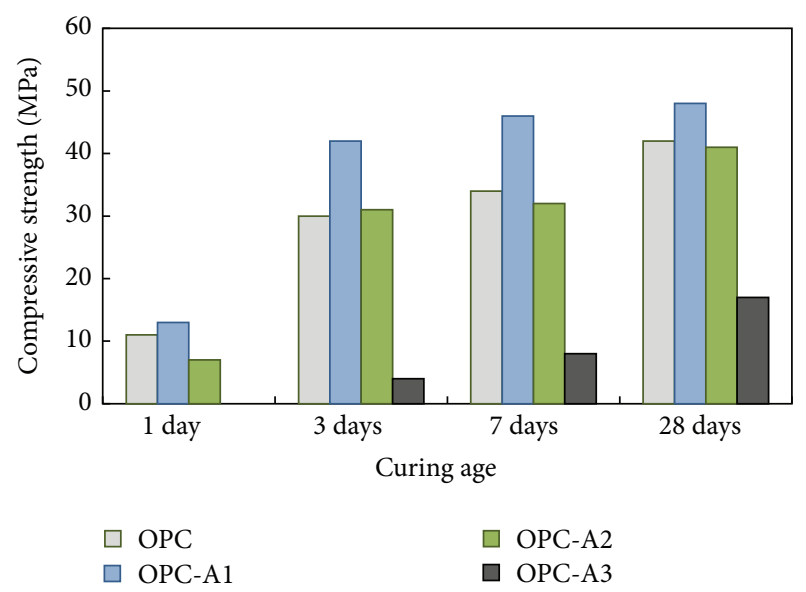

(a) Specimen incorporating calcium acetate

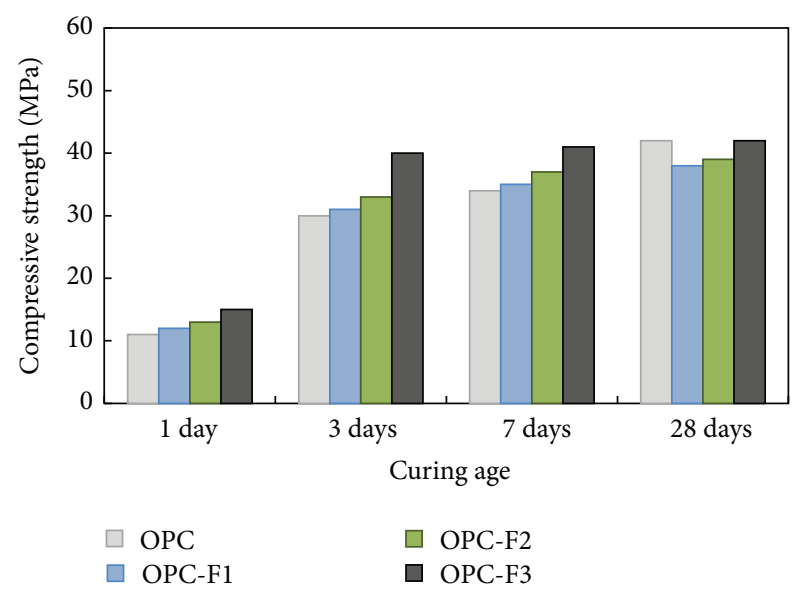

(b) Specimen incorporating calcium formate

FIGURE 8: Compressive strength of specimens.

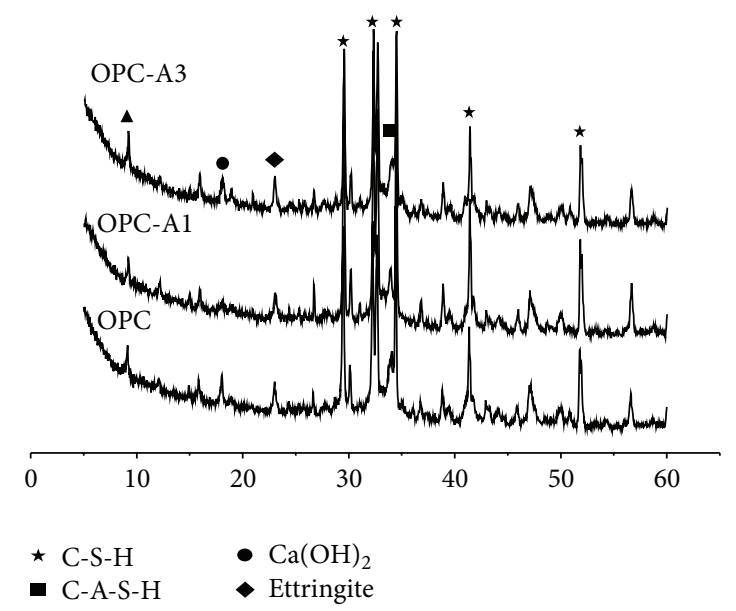

FIGURE 9: Specimen incorporating calcium acetate (1 day).

was also lower. In contrast, the intensity of the ettringite peak increased as the CA content increased.

The XRD patterns of the CF-mortars with different CF contents after a curing period of one day are shown in Figure 10. When 1\% CF was mixed, the intensity of both the $\mathrm{Ca}(\mathrm{OH})_{2}$ and $\mathrm{C}-\mathrm{A}-\mathrm{S}-\mathrm{H}$ peaks increased. When $3 \% \mathrm{CF}$ was mixed, the intensity of both the $\mathrm{Ca}(\mathrm{OH})_{2}$ and C-A-S-H peaks decreased, while that of the ettringite and C-S-H peaks increased. As reported by Heikal [36], the diffusion rate of $\mathrm{HCOO}^{-}$ions is greater than that of $\mathrm{Ca}^{2+}$ ions. Therefore, it is possible for $\mathrm{HCOO}^{-}$ions to penetrate into the protective layer of C-S-H. As a result, the C-S-H decomposition is directly proportional to the deposition of $\mathrm{Ca}(\mathrm{OH})_{2}$. In addition, Ramachandran [37] stated that the presence of $\mathrm{COOH}^{-}$ions promotes the hydration of $\mathrm{C}_{3} \mathrm{~S}$ by interfering with the protective layer of cement particles, which ultimately leads to the formation of ettringite. It was found that the structure of the CA- and CF-mortars containing 1\% CA and $\mathrm{CF}$, respectively, was similar, and both the mortars enhanced

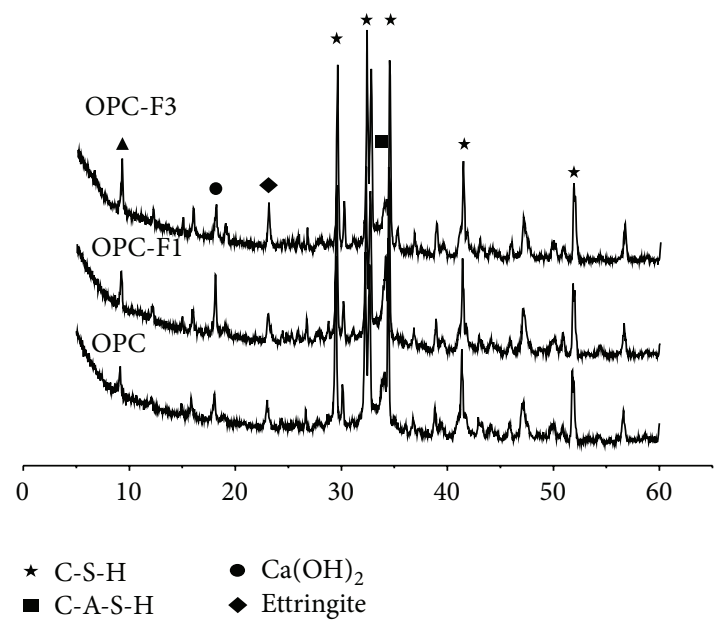

FIgURE 10: Specimen incorporating calcium formate (1 day). the production of C-A-S-H, ettringite, and C-S-H during the initial early stages of concrete formation [38].

The XRD patterns of the CA- and CF-mortars cured for three days are shown in Figures 11 and 12, respectively. In the case of the CA-mortar containing 1\% CA, ettringite, the $\mathrm{Ca}(\mathrm{OH})_{2}$, and $\mathrm{C}-\mathrm{A}-\mathrm{S}-\mathrm{H}$ peaks were more intense, as shown in Figure 11. When 3\% CA was mixed, the intensity of the $\mathrm{Ca}(\mathrm{OH})_{2}$ and $\mathrm{C}-\mathrm{A}-\mathrm{S}-\mathrm{H}$ peak decreased, while that of the ettringite and $\mathrm{C}-\mathrm{S}-\mathrm{H}$ peaks increased. In the case of the CAmortar containing $1 \% \mathrm{CF}$, ettringite, the $\mathrm{Ca}(\mathrm{OH})_{2}$, and C-A$\mathrm{S}-\mathrm{H}$ peaks were more intense, as shown in Figure 11. When $3 \% \mathrm{CA}$ was mixed, the intensity of the $\mathrm{Ca}(\mathrm{OH})_{2}$ and C-A-S$\mathrm{H}$ peak decreased, while that of the ettringite peaks increased as shown in Figure 12.

When $\mathrm{Al}$ ion content is the same, $\mathrm{Ca}(\mathrm{OH})_{2}$ and C-A-S$\mathrm{H}$ increase according to the increase of $\mathrm{Ca}$ ion [39]. Thus, when $\mathrm{CA}$ and $\mathrm{CF}$ contents are $1 \%, \mathrm{Ca}(\mathrm{OH})_{2}$ and $\mathrm{C}-\mathrm{A}-\mathrm{S}-\mathrm{H}$ increased. On the other hand, according to the increase of CA and CF contents, $\mathrm{Ca}(\mathrm{OH})_{2}$ and C-A-S-H peaks decreased. 


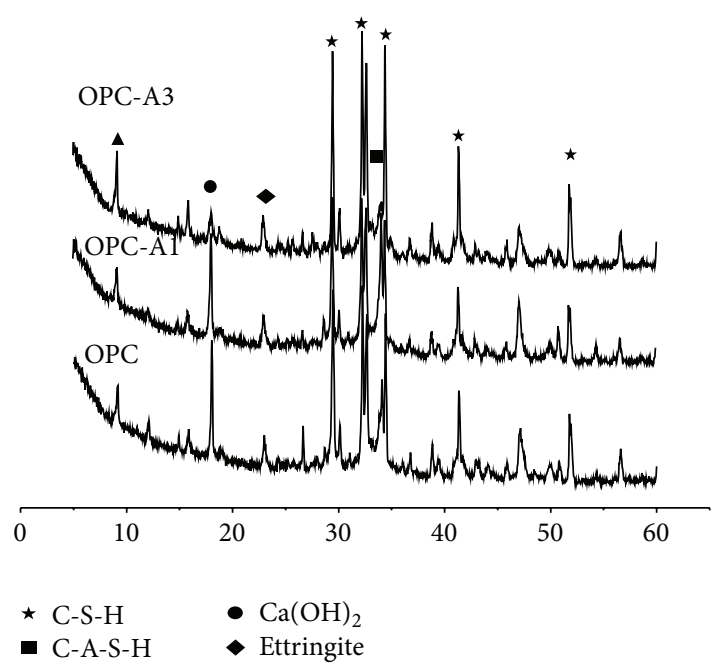

FIGURE 11: Specimen incorporating calcium acetate (3 days).

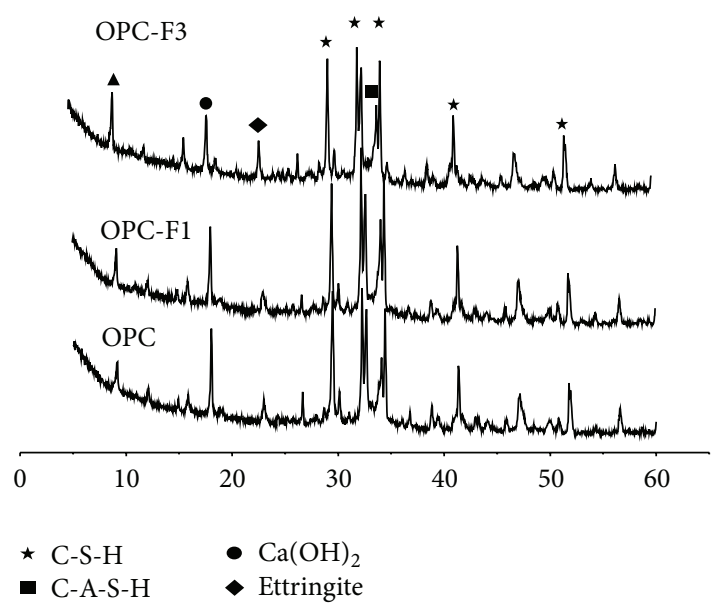

FIGURE 12: Specimen incorporating calcium formate (3 days).

While the $\mathrm{pH}$ of $\mathrm{CF}$ is 7.0 and its solubility is $166 \mathrm{~g} / \mathrm{L}$, the $\mathrm{pH}$ of CA is about 5.9 and its density is $247 \mathrm{~g} / \mathrm{L}$. High solubility of CA affected both ettringite generation and decrease of $\mathrm{Ca}(\mathrm{OH})_{2}$ and C-A-S-H peaks [40].

\section{Conclusions}

CA was manufactured using acetic acid and LSS obtained from industrial by-products, and its characteristics were examined. The performances of the cementitious composites mixed with this manufactured CA were evaluated. On the basis of the results obtained, the following conclusions were made:

(1) The $\mathrm{pH}$ of the $\mathrm{CA}$ manufactured via the reaction of $\mathrm{CaCO}_{3}$ and LSS was found to be the same as that of the $\mathrm{CA}$ manufactured using $\mathrm{CaCO}_{3}$ (5.9). The microelemental analysis showed that the heavy metal content in the manufactured CA was lower than the detection limits.
(2) The compressive strength of the CA-mortars was maximum when $1 \%$ CA was mixed. This value of compressive strength was more than that obtained when no admixture was added even when the specimens were cured for 28 days. In particular, on the 28th day, the CA-mortar showed a higher compressive strength than that of the CF-mortar.

(3) For the cement pastes mixed with $\mathrm{CF}$, the $\mathrm{pH}$ remained constant at all the mixing ratios. However, when the CF content exceeded 1\%, CA, which is more acidic, had a greater influence on the mixture, leading to a reduction in the $\mathrm{pH}$ and strength of the cement, for the hydrates of the hardened cement pastes mixed with the $\mathrm{CA}$ and $\mathrm{CF}$, which is advantageous for the enhancement of the C-S-H and ettringite.

(4) Finally, we can conclude that the CA is manufactured using the recycled industrial by-products functions as an effective HESA for cement composites.

\section{Competing Interests}

The authors declare that there are no competing interests regarding the publication of this paper.

\section{Acknowledgments}

This research was supported by a Grant (15CTAP-C07792902) from Technology Advancement Research Program funded by Ministry of Land, Infrastructure and Transport of Korean government.

\section{References}

[1] ACI, "Accelerated curing of concrete at atmospheric pressurestate of the art," ACI Committee 517.2R-87, American Concrete Institute, 1992.

[2] ACI, Building Code Requirements for Structural Concrete, ACI Committee 318, American Concrete Institute, Farmington Hills, Mich, USA, ACI 318-95 edition, 1995.

[3] ACI, Building Code Requirements for Structural Concrete, ACI Committee 318, American Concrete Institute, Farmington Hills, Mich, USA, ACI 318-99 edition, 1999.

[4] ACI, Building Code Requirements for Structural Concrete, ACI Committee 318, American Concrete Institute, Farmington Hills, Mich, USA, ACI 318-02 edition, 2002.

[5] ACI, Building Code Requirements for Structural Concrete, ACI Committee 318, American Concrete Institute, Farmington Hills, Mich, USA, ACI 318-05 edition, 2005.

[6] ACI, Building Code Requirements for Structural Concrete, ACI Committee 318, American Concrete Institute, Farmington Hills, Mich, USA, ACI 318-08 edition, 2008.

[7] T. Soleymani, V. Trianni, M. Bonani, F. Mondada, and M. Dorigo, "Bio-inspired construction with mobile robots and compliant pockets," Robotics and Autonomous Systems, vol. 74, pp. 340-350, 2015.

[8] A. M. Ramezanianpour, K. Esmaeili, S. A. Ghahari, and A. A. Ramezanianpour, "Influence of initial steam curing and 
different types of mineral additives on mechanical and durability properties of self-compacting concrete," Construction and Building Materials, vol. 73, pp. 187-194, 2014.

[9] S. Aggoun, M. Cheikh-Zouaoui, N. Chikh, and R. Duval, "Effect of some admixtures on the setting time and strength evolution of cement pastes at early ages," Construction and Building Materials, vol. 22, no. 2, pp. 106-110, 2008.

[10] K. Hoang, H. Justnes, and M. Geiker, "Early age strength increase of fly ash blended cement by a ternary hardening accelerating admixture," Cement and Concrete Research, vol. 81, pp. 59-69, 2016.

[11] F. Messina, C. Ferone, F. Colangelo, and R. Cioffi, "Low temperature alkaline activation of weathered fly ash: influence of mineral admixtures on early age performance," Construction and Building Materials, vol. 86, pp. 169-177, 2015.

[12] C. Çetin, S. T. Erdoğan, and M. Tokyay, "Effect of particle size and slag content on the early hydration of interground blended cements," Cement and Concrete Composites, vol. 67, pp. 39-49, 2016.

[13] G. Le Saoût, B. Lothenbach, A. Hori, T. Higuchi, and F. Winnefeld, "Hydration of Portland cement with additions of calcium sulfoaluminates," Cement and Concrete Research, vol. 43, no. 1, pp. 81-94, 2013.

[14] H. Huang and X.-D. Shen, "Interaction effect of triisopropanolamine and glucose on the hydration of Portland cement," Construction and Building Materials, vol. 65, pp. $360-$ 366, 2014.

[15] T.-B. Min, I.-S. Cho, W.-J. Park, H.-K. Choi, and H.-S. Lee, "Experimental study on the development of compressive strength of early concrete age using calcium-based hardening accelerator and high early strength cement," Construction and Building Materials, vol. 64, pp. 208-214, 2014.

[16] B. E. I. Abdelrazig, D. G. Bonner, D. V. Nowell, J. M. DransField, and P. J. Egan, "Effects of accelerating admixtures on cement hydration, admixture for concrete," in Improvement of Properties, pp. 120-136, Chapman and Hall, Barcelona, Spain, 1990.

[17] R. Chidara, R. Nagulagama, and S. Yadav, "Achievement of early compressive strength in concrete using Sporosarcina pasteurii bacteria as an admixture," Advances in Civil Engineering, vol. 2014, Article ID 435948, 7 pages, 2014.

[18] X. Zhu, H. Hou, X. Huang, M. Zhou, and W. Wang, "Enhance hydration properties of steel slag using grinding aids by mechanochemical effect," Construction and Building Materials, vol. 29, pp. 476-481, 2012.

[19] J. Han, K. Wang, J. Shi, and Y. Wang, "Mechanism of triethanolamine on Portland cement hydration process and microstructure characteristics," Construction and Building Materials, vol. 93, pp. 457-462, 2015.

[20] E. Erdem, M. E. Günay, and R. Donat, "Hydration and mechanical properties of Portland cement containing eloxal waste from aluminium industry," Journal of Materials Processing Technology, vol. 136, no. 1-3, pp. 35-38, 2003.

[21] W. Li, S. Ma, Y. Hu, and X. Shen, “The mechanochemical process and properties of Portland cement with the addition of new alkanolamines," Powder Technology, vol. 286, pp. 750-756, 2015.

[22] H. Justnes and E. C. Nygaard, "Technical calcium nitrate as set accelerator for cement at low temperatures," Cement and Concrete Research, vol. 25, no. 8, pp. 1766-1774, 1995.

[23] P. C. Hewlett, Lea's Chemistry of Cement and Concrete, Arnold, London, UK, 4th edition, 1988.
[24] C.-H. Shin, J.-Y. Kim, J.-Y. Kim et al., "Recovery of nitric acid from waste etching solution using solvent extraction," Journal of Hazardous Materials, vol. 163, no. 2-3, pp. 729-734, 2009.

[25] World Steel Association, "November 2015 crude steel production," 2015, https://www.worldsteel.org/media-centre/pressreleases/2015/November-2015-crude-steel-production-.html.

[26] S. K. Seo, Y. S. Chu, K. B. Shim, J. K. Lee, H. Song, and Y. M. Yun, "A study on the application limestone sludge to the flue gas desulfurization process," Journal of the Korean Ceramic Society, vol. 51, no. 6, pp. 575-583, 2014.

[27] N. A. Aslam and S. A. Babu, "Direct lactonization of $\alpha$-amino $\gamma, \delta$-unsaturated carboxylic acid esters via olefin activation: stereo- and regioselective production of homoserine lactone scaffolds having contiguous stereocenters," Tetrahedron, vol. 70, no. 37, pp. 6402-6419, 2014.

[28] ASTM, "Standard Test Methods for Rheological Properties of Non-Newtonian Materials by Rotational Viscometer," ASTM D 2196, 2015.

[29] ASTM, "Standard Test Method for Density, Relative Density, and API Gravity of Liquids by Digital Density Meter," ASTM D 4052-11, 2011.

[30] ASTM, "Standard practice for preparation of water samples using reductive precipitation preconcentration technique for ICP-MS analysis of trace metals," ASTM D 6800-12, 2012.

[31] ASTM, "Standard test Method for time of Setting of Hydraulic cement by Vicat needle," ASTM C 191, 2006.

[32] ASTM, "Standard specification for flow table for use in tests of hydraulic cement," ASTM C230/230M-14, 2014.

[33] ASTM, "Test method for compressive strength of hydrolic cement mortars," ASTM C109, 2006.

[34] Japan Society of Civil Engineers, Concrete Library 111, Leaching Minor Elements from Concrete, Japan Society of Civil Engineers, Tokyo, Japan, 2005.

[35] E. A. Bortoluzzi, N. J. Broon, M. A. Hungaro Duarte, A. C. C. de Oliveira Demarchi, and C. M. Bramante, "The use of a setting accelerator and its effect on $\mathrm{pH}$ and calcium ion release of mineral trioxide aggregate and white portland cement," Journal of Endodontics, vol. 32, no. 12, pp. 1194-1197, 2006.

[36] M. Heikal, "Effect of calcium formate as an accelerator on the physicochemical and mechanical properties of pozzolanic cement pastes," Cement and Concrete Research, vol. 34, no. 6, pp. 1051-1056, 2004.

[37] V. S. Ramachandran, Concrete Admixtures Handbook: Properties, Science and Technology, chapter 3, Noyes Publications, New York, NY, USA, 2nd edition, 1995.

[38] S. Popovics, "Admixtures," in Concrete Materials: Properties, Specifications, and Testing, chapter 6, pp. 236-246, William Andrew Publishing/Noyes Publications, 2nd edition, 1992.

[39] K. Scrivener, R. Snellings, and B. Lothenbach, A Practical Guide to Microstructural Analysis of Cementitious Material, CRC Press, New York, NY, USA, 2016.

[40] V. Dodson, Concrete Admixtures, chapter 4, Van Nostrand Reinhold, New York, NY, USA, 1990. 

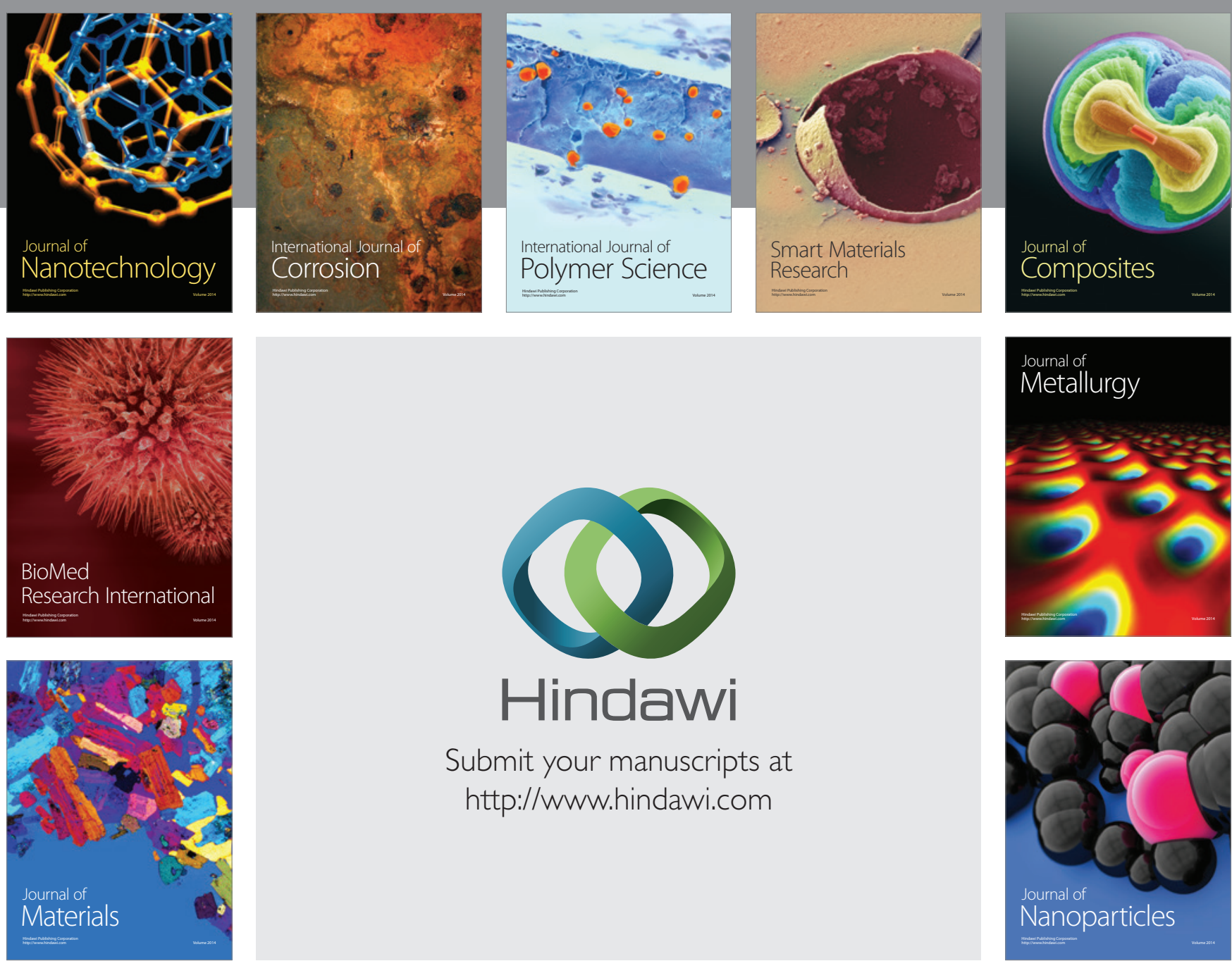

\section{Hindawi}

Submit your manuscripts at

http://www.hindawi.com

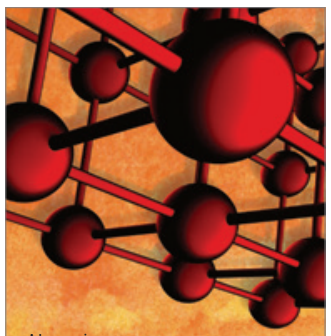

Materials Science and Engineering
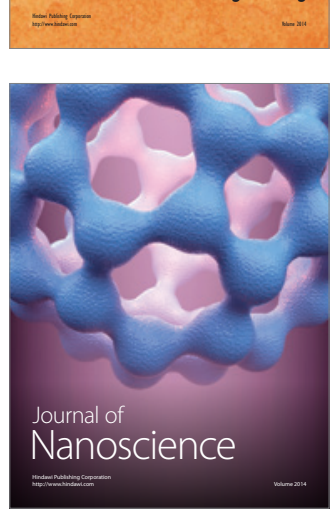
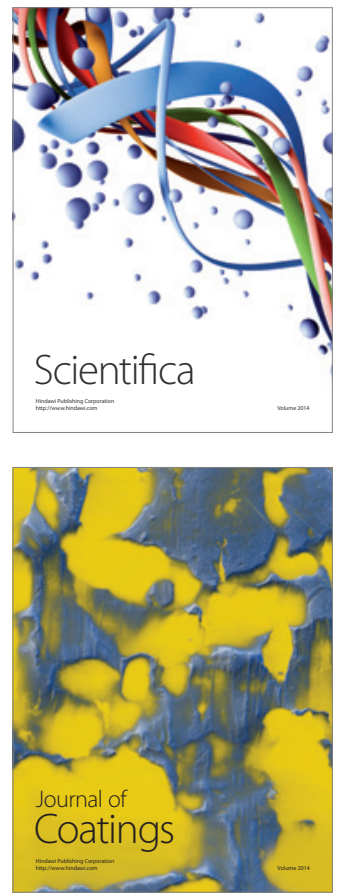
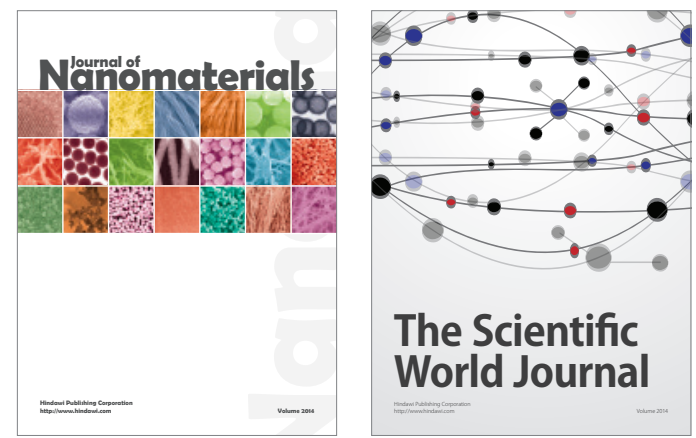

The Scientific World Journal
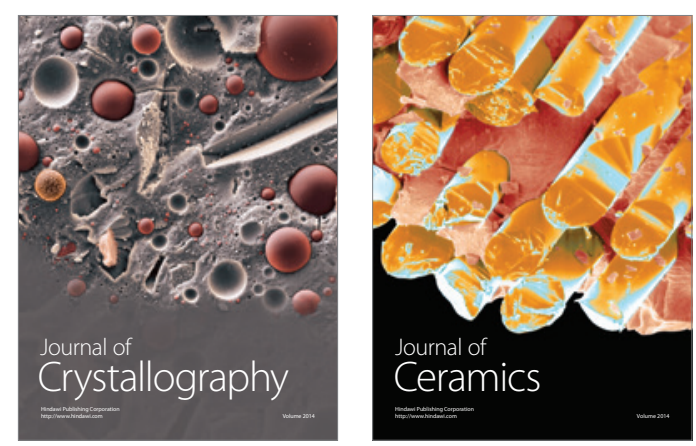
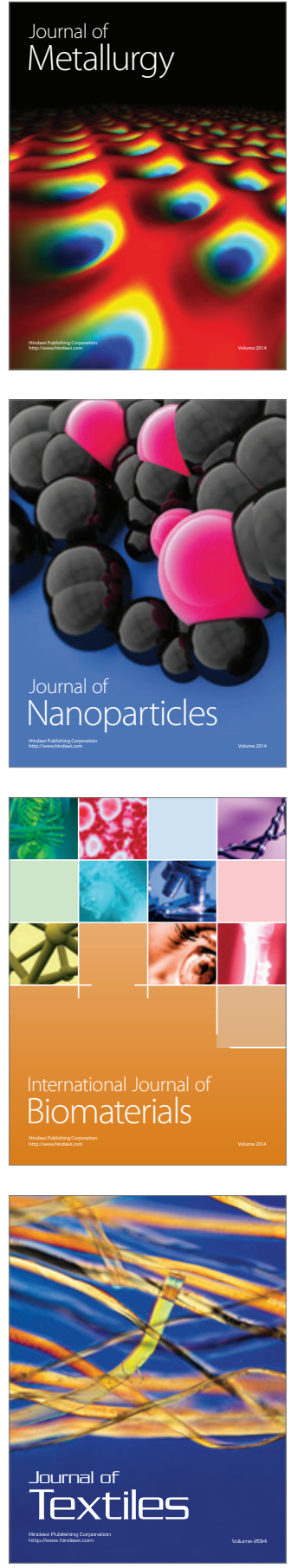